\title{
Influence of Polymer Concentration on Membrane Performance in Wastewater Treatment
}

\author{
LAURENTIA GEANINA TIRON, STEFAN CATALIN PINTILIE, ANDREEA LILIANA LAZAR, MARIA VLAD, STEFAN BALTA*, \\ MARIUS BODOR \\ Dunarea de J os University of Galati, 47 Domneasca Str., 800008, Romania
}

\begin{abstract}
Water is an important element of life, while every industry in its processes uses an important amount of water. Following processes, the water is contaminated and requires water treatment technologies. Unconventional methods to wastewater treatment, in the last years, use membrane technology as one of the most reliable processes for contaminants removal. In this article, the influence of the different concentrations of polysulfone (PSf) on the polymeric membranes properties was studied. These membranes were obtained through phase inversion method and with different polymer concentrations: 23, 25, 27 and 30 wt.\%. The performance of the membranes was studied by pure water flux, permeability and retention. It has been observed that by increasing the polymer concentration, the pure water flux and the permeability will decrease. Retention was determined using methylene blue, which is one of the most utilized dye from industry and it could be observed that by increasing the polymer concentration the retention degree of the pollutant also increases. In order to explain the evolution of membrane permeability at different polymer concentrations, surface hydrophilicity by contact angle method and cross-section SEM imaging were used.
\end{abstract}

Keywords: polymer membranes, polysulfone (PSf), pure water flux, permeability, retention

The contaminated water can be treated by applying an alternative method like membrane removal technology [1]. Big quantities of wastewater are generated from various industries which are considered as the major threat of environment [2-4].

Polymeric membranes technology is using pressure as driving force and can be used to separate two different phases $[5,6]$. In this study liquid-liquid separation is used. Applying membrane separation to remove particles with different dimensions (micro and macro) depends if the process is microfiltration or ultrafiltration [7]. Ultrafiltration is a process widely used in multiple industries to separate pollutants or to recover some substances like in water treatment, in chemical and pharmaceutical industry [8]. Membranes used in ultrafiltration (UF) are obtained by phase inversion technique [9] and involves morphology characteristics: thin dense layer, porous support layer [10, 11]. Membrane nanofiltration is a process that is used often to remove synthetic organic compounds, water hardness, natural organic matter and also ions [12].

Due to the strength of separation and selectivity properties given by the polymeric membranes, researchers all around the world have become interested [13]. In comparison with the conventional technologies, the membrane technology uses less energy and less space $[14,15]$.

The polymer solution introduced in the non-solvent bath (pure water) occurs the evaporation of the solvent from the solution, this phenomenon has a strong influence on the transport properties [16]. The obtained membrane has two layers, the support layer offers mechanical strength and the top layer formed by the polymer solution is a dense layer which retain impurities from the pollutant [11].

Fouling is a phenomena which occurs on membrane technology because of particles blocked on the membrane structure [17, 18] that reduce the permeate flux [19]. By blocking the membrane pores with foulants it can been seen that pure water flux is reduced [20], this phenomena is most common in membrane as fouling [21]. Fouling problems can be avoided by increasing the hydrophilicity of the membrane, because this type of membranes are more attracted to water [22]. On the other hand, hydrophobic membranes present low water flux [23-26] and can suffer severe problems of fouling. This is the main reason for studying the influence of membrane properties on their performance [24]. To improve membrane properties, the membrane structure can be controlled by different techniques like chemical treatment, blending and coating to increase the water permeability of the membranes [22].

Polysulfone is a polymer with good mechanical strength, chlorine tolerance and thermal stability [26-29], it is used in membrane technology especially in ultrafiltration [11, 30]. Polysulfone is a hydrophobic polymer, that means is nonwettable by water and requires high pressure for water to pass to the membrane pores [31].

\section{Experimental part}

Materials and membrane characterization

The polymer solution was obtained by dissolving polysulfone (PSf) in solvent 1-methyl-2-pyrrolidone (NMP, $99 \%)$, all the materials were purchased from SigmaAldrich. The polymer solution was applied on the support layer (Viledon F02471) obtained from Freudenberg (Winheim, Germany).

\section{Membrane preparation}

The polysulfone with different weight percentage was added in the solvent under continuous stirring. The manufacturing process was based on phase inversion process from liquid phase to solid phase. The polymer and the solvent concentrations used to obtain the membranes are presented in table 1.

The membranes were obtained by applying a thin film of the solution on the support layer using the Automatic Film Applicator PA-2101 (BYC-Gardner $\mathrm{GmbH}$ ) and a special knife to provide the required film thickness [32].

* email: stefan.balta@ugal.ro 
Table 1

MEMBRANE TYPE DEPENDING OF THE POLYMER AND SOLVENT CONCENTRATIONS

\begin{tabular}{|c|c|c|}
\hline $\begin{array}{c}\text { Membrane } \\
\text { no. }\end{array}$ & $\begin{array}{c}\text { PSf concentration } \\
\text { [wt.\%] }\end{array}$ & $\begin{array}{c}\text { NMP concentration } \\
\text { [wt.\%] }\end{array}$ \\
\hline PSf-1 & 23 & 77 \\
\hline PSf-2 & 25 & 75 \\
\hline PSf-3 & 27 & 73 \\
\hline PSf-4 & 30 & 70 \\
\hline
\end{tabular}

The film was immersed in a bath of distilled water for at least $15 \mathrm{~min}$. The membranes formed were washed with distilled water and stored wet, until characterization.

\section{Membrane characterization}

Flux and permeability of membranes

All permeation experiments were carried at operating pressures ranging from 6 to 12 bar in a Dead-End stirred cell (Sterlitech HP4750 Stirred Cell).

The pure water flux was studied by measuring the filtration time of $5 \mathrm{~mL}$ for a total volume of $150 \mathrm{~mL}$ and calculated by the following relation:

$$
J_{W}=\frac{V}{A \times \Delta t}
$$

where:

$J_{w}$ - permeate flux $\left[\mathrm{L} / \mathrm{m}^{2}, \mathrm{~h}\right], \mathrm{V}$ - volume $[\mathrm{mL}], A$ membrane area $\left[\mathrm{m}^{2}\right]$ and $\Delta \mathrm{t}$ - filtering time of permeate volume [h] [34].

The relative flux of the membrane, the relation between initial pure water flux of the membrane and the retention flux, is obtained by using the relation:

$$
J_{R}=\frac{J_{0}}{J_{w}}
$$

where:

$J_{R}$ - relative flux $\left[\mathrm{L} / \mathrm{m}^{2} \cdot \mathrm{h}\right]$

$\int_{0}^{R}$-dye retention $\left[\mathrm{L} / \mathrm{m}^{2}, \mathrm{~h}\right]$

To determine the permeability of the membrane, the pressure gradient was varied and then applied to the filter cell, then the time unit for $10 \mathrm{~mL}$ of distilled water was measured.

Permeability of pure water was calculated using the pure water flux $\left(J_{W}\right)$ and operating pressure $(\Delta P)$ according to the relation:

$$
\mathrm{PWP}=\frac{\mathrm{JW}}{\Delta \mathrm{P}}
$$

Surface hydrophilicity of studied membranes

The hydrophilicity property refers to the affinity of a surface for water. If the surface is hydrophilic, the contact angle between the water droplet and the observed surface is as small as possible, and if the contact angle is greater, then the surface is more hydrophobic.

Polysulfone is a hydrophobic material, and the obtained membranes are influenced both by the used polymer and by its concentration.

The surface hydrophilicity was evaluated by using a contact angle goniometer (OCA 15EC, DataPhysics). The samples were dried at $50^{\circ} \mathrm{C}$ for $24 \mathrm{~h}$ and the dropping was repeated for several times for each sample.

\section{Retention test}

Retention properties of the obtained membranes, with four different concentrations of polysulfone, was tested with a solution of methylene blue (molecular weight:

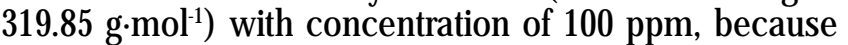

the removal of dyes from wastewater from textile industry is considered an environmental challenge [34].

The concentration of the dye solution was determined spectroscopically using the HACH DR 5000 UV-Vis Spectrometer (Hach Lange GmbH, Germany).

The ratio was calculated using the following formula:

$$
\text { Retention }[\%]=\left(1-\frac{c_{f}}{c_{0}}\right) \cdot 100
$$

where:

$C$ represents the concentration of the dye in the initial solution (100 ppm) and $C_{f}$ is the concentration of the obtained solution.

\section{Results and discussions}

Measurements of pure water flux and permeation

The influence of the polymer concentration on the membrane flux was studied by analyzing four different concentrations of polysulfone: $23,25,27$ and $30 \mathrm{wt} . \%$ ( fig. 1).

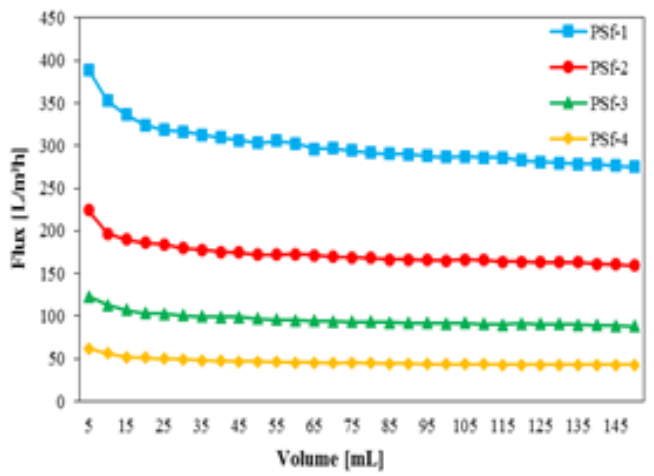

Fig. 1. The pure water flux variation of the membrane

In figure 1 it was observed that the flux of a membrane depends on the concentration of the polymer. Increasing the concentration of the polymer leads to a decrease in water flux but an increase in stability. The membrane PSf4 (30 wt.\% PSf) show the most stable flux comparing with the membrane PSf-1 (23 wt.\% PSf) which has an initial flux of $362.61\left[\mathrm{~L} / \mathrm{m}^{2} . \mathrm{h}\right]$ and decrease to $233\left[\mathrm{~L} / \mathrm{m}^{2} . \mathrm{h}\right]$, meaning a decrease in pure water flux of $36 \%$. The antifouling property of membranes is measured by the relative flux between pure water flux and dye flux. When the relative flux value tends to 1 , fouling is at minimum. On the other side, if the relative flux tends to 0 , fouling is at maximum and the membranes are not a good choice for filtration. In the figure 2 it can be seen that the membranes with a concentration of $23 \mathrm{wt} . \%$ (PSf-1) and $27 \mathrm{wt} . \%$ (PSf3) has lower relative flux compared with the membrane PSf-2 and PSf-4. The membrane PSf-2 has the highest and the most stable relative flux, meaning that fouling is almost non-existent. For the membrane PSf- 4 the retention of 150 $\mathrm{mL}$ of dye has also a low fouling phenomena. This phenomenon mainly is caused by adsorption or

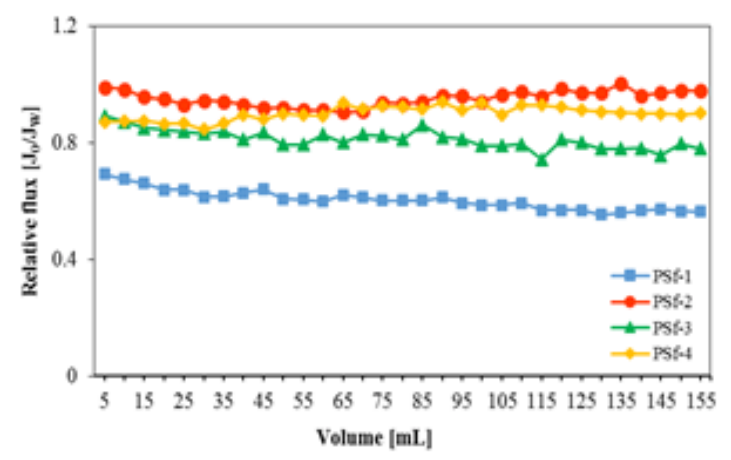

Fig. 2. The evolution of relative flux of membrane 
crystallization, possibly enhanced by pore blocking and/or cake formation [35].

\section{Membrane hydrophilicity}

Modifying the membranes by increasing the concentration of the polymer in the coagulation solution, results in influences on the hydrophilicity properties of the membranes. In the present case, the membranes were obtained from the same polymer but with four different concentrations. It is observed that the higher polymersolvent ratio, the more rejecting water property of polysulphone is accentuated. In other words, the membranes with $30 \mathrm{wt} . \% \mathrm{PSf}$ are more hydrophobic than those with lower concentrations.

As seen in figure 3 , the contact angle increases with the concentration of the polymer while, the porosity of the membrane decreases as the polymer concentration increases. The higher concentration of polymer in the membrane means that the solvent in the solution has a lower ratio and when it evaporates it forms smaller pores. This may explain the decrease in membrane porosity while the polymer concentration is higher.

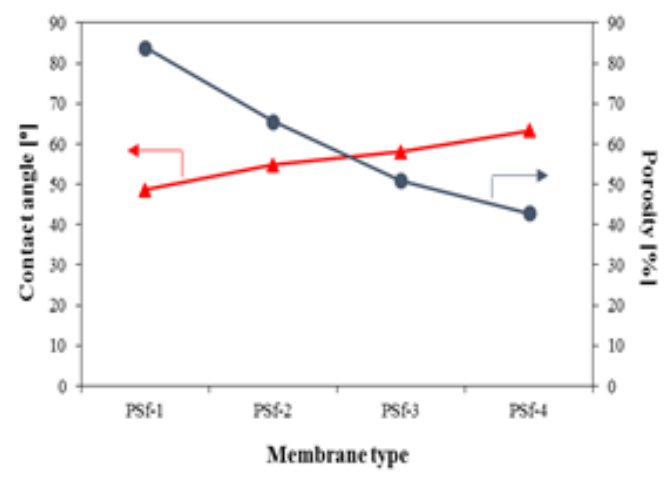

Fig. 3. Evolution of water affinity and porosity of the membranes depending on the polymer concentration

\section{Rejection measurements}

The different concentrations of polymer have an influence on the retention tests of methylene blue dye. The membrane PSf-4 has better retention because of its morphological structure caused by the higher polymer concentration that provides two different layers of pours structures, phenomena reported also by Ciucureanu A. et. all. [36].

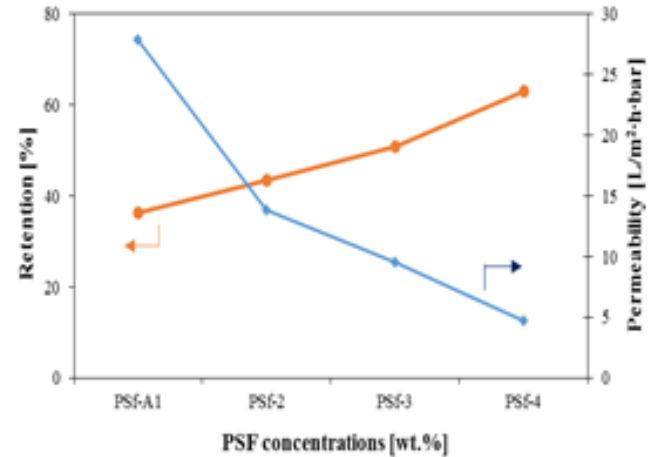

Fig. 4. Retention properties of tested membranes

Distilled water permeability is inversely proportional with the polymer concentration increase, thus maintaining the same trend as in the case of distilled water flux.

The membranes PSf-1 and PSf-2 have a high permeability through low concentration of polymer in the casting solution.

The PSf-1 sample has a permeability of $27.92\left[\mathrm{~L} / \mathrm{m}^{2} \mathrm{~h}\right.$ bar], increasing the polymer concentration by two percent at $25 \mathrm{wt} \% \mathrm{PSf}$, the permeability drops to $13.85\left[\mathrm{~L} / \mathrm{m}^{2} . \mathrm{h}\right.$. bar], with a decrease of about $54 \%$. The percentage of PSf-4 membrane permeability decreases to PSf-1 membrane permeability by approximately $80 \%$.

\section{Membranes morphology}

Figure 5 shows cross-section SEM images of different membranes prepared with different concentrations. In this figure, it can be seen that the formed membranes have an asymmetrical structure consisting of a dense top layer and a porous substrate. The substrate appears to have fingerlike cavities as well as a macrovoid structure.

These finger-like cavities and the macrovoid structure, as seen in figure 5 , differ depending on the increase in PSf polymer concentration. At the time when the porous substrate exhibits an elongated pore structure, such as the PSf membrane with $23 \mathrm{wt} \%$, it usually leads to increased permeability (fig. 2).

By analyzing the samples, it is observed that if the polymer concentration is lower, the upper layer of the membrane is thicker and the pore size is higher. In contrast, for membranes with a concentration of $30 \mathrm{wt}$. $\mathrm{PSf}$, the upper layer is thinner with pores even smaller in size.
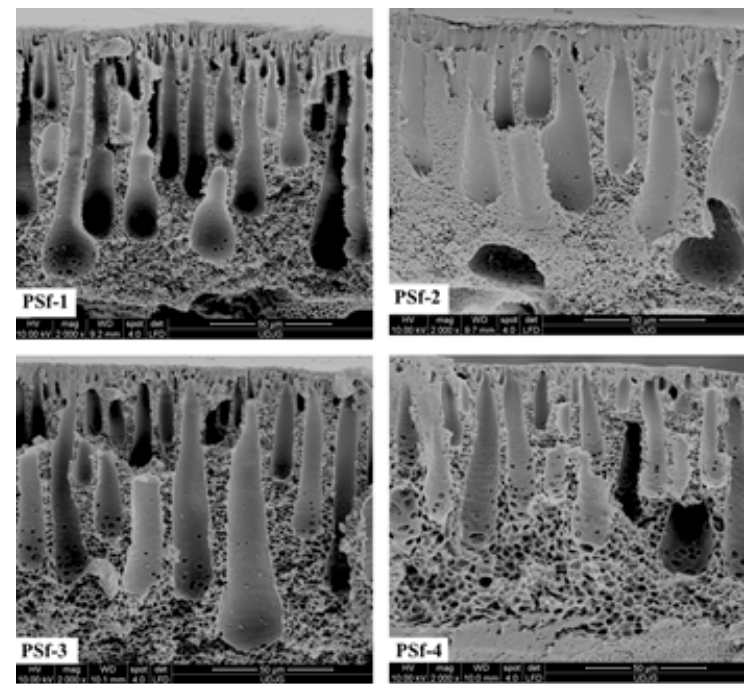

Fig. 5. SEM images of membranes cross sections

\section{Conclusions}

Polysulfone ultrafiltration membranes were fabricated by phase inversion technique with different polymer concentration. The retention of the samples was improved by the high polymer ratio but the flow and the affinity to water decreased.

The flux and the rejection performance of PSf membranes changed by changing the polymer concentration, the permeability decreased from $27.92 \mathrm{~L} /$ $\mathrm{m}^{2} \cdot h \cdot$ bar for $23 \mathrm{wt}$. $\%$ PSf to $4.74 \mathrm{~L} / \mathrm{m}^{2} \cdot h \cdot$ bar for $30 \mathrm{wt}$. $\% \mathrm{PSf}$, respectively the retention increased from $29.61 \%$ (23 wt.\% PSf) to $59.65 \%$ (30 wt.\% PSf). The samples with more porous structure show good properties through a relatively higher flux in short term test.

Analyzing the polymer concentration influence on the membrane properties, the best retention for tested membranes is that of membrane PSf-4 (with $30 \mathrm{wt}$.\% PSf) due to the top layer with small pores. The retention of this membrane increase in rejection of methylene blue dye can be related to a moderate reduction in the porosity that results in a decrease of the water permeation.

Usually, in the attempt to improve membranes, it has been observed in literature that the growth of a property leads to the decline of another property. In the present case, a favorable choice would be the optimal ratio between retention and permeability, obtained by membrane PSf- 2 . 
In addition, water quality requirements vary from industry to industry. To this extent, for the industry where the severity of water quality and purity control is not so high, one can opt for the type of membrane that has the highest flux even if the retention capacity is low. On the other hand, if water quality is considered a priority, it is imperative to focus on high retention capacity at the expense of lower flux. All the membranes studied in this article can be adapted according to the needs demanded by industries.

\section{References}

1. MULIWA, A.M., LESWIFI, T.Y., ONYANGO, M.S., MAITY, A., Sep. Purif. Technol., 158, 2016, p. 250-258.

2. LI, C., SONG, C., TAO, P., SUN, M., PAN, Z., WANG, T., SHAO, M., Sep. Purif. Technol., 168, 2016, p. 47-56.

3. LU, Y., SUN, H., MENG, L.L., YU, S.L., Sep. Purif. Technol., 66, 2009, p. 347-352.

4. GHIMPUSAN, M., NECHIFOR, G., SPIRIDON, I., NECHIFOR, A.C., PASSERI, P., Mat. Plast., 53, no. 4, 2016, p. 578

5. DUBREUIL, M.F.S., SERVAES, K., ORMEROD, D., VAN HOUTVEN, D., PORTO-CARRERO, W., VANDEZANDE, P., VANERMEN, G., BUEKENHOUDT, A., Sep. Purif. Technol., 178, 2017, p. 56-65.

6. SIMIONESCU, S., TEODORESCU, S., ION, R.M., VOICILA, E., NECHIFOR, G., Mat. Plast., 54, no.1, 2017, p. 194

7. SANDEFUR, H.N., ASGHARPOUR, M., MARIOTT, J., GOTTBERG, E., VADEN, J., MATLOCK, M., HESTEKIN, J., Ecol. Eng., 94, 2016, p. 75-81. 8. XU, C., LIU, X., XIE, B., YAO, C., HU, W., LI, Y., LI, X., Appl. Surf. Sci., 385, 2016, p. 130-138.

9. DIMA, S.O., SARBU, A., DOBRE, T., BRADU, C., ANTOHE, N., RADU, A.L., NICOLESCU, T.V., LUNGU, A., Mat. Plast., 46, no.4, 2009, p. 372 10. BALTA, S., BURUIANA, D.L., SIMIONESCU, C.S., TIRON, L.G., BORDEI, M., VAN DER BRUGGEN, B., Desalin. Water Treat., 57, 2016, p. 13924-13929.

11. KUMAR, S., MANDAL, A., GURIA, C., Process Saf. Environ. Prot., 102, 2016, p. 214-228.

12. NGUYEN, H.X., VAN DER BRUGGEN, B., J. Membr. Sci. Res., 1, 2015, p. 34-40.

13. SEGARCEANU, M., PASCU, D.E., TRAISTARU, G.A., PASCU (NEAGU), M., Rev. Chim. (Bucharest), 65, no.1, 2014, p. 8

14. TEODORESCU, S., ORBECI, C., PASCU, D.E., NECHIFOR, A.C., PASCU (NEAGU), M., TRAISTARU, G.A., BUNACIU, A.A., PASCU, L.F., TOTU, M., Rev. Chim. (Bucharest), 66, no.3, 2015, p. 868
15. AYYAVOO, J., NGUYEN, T.P.N., JUN, B.M., KIM, I.C., KWON, Y.N., Colloids Surf. A Physicochem. Eng. Asp., 506, 2016, p. 190-201.

16. TSAY, C.S., MCHUGH, A.J ., J. Polym. Sci., Part B Polym. Phys., 29, 1991, p. 1261-1270.

17. YAN, Z., LIU, B., QU, F., DING, A., LIANG, H., ZHAO, Y., LI, G., Sep. Purif. Technol., 172, 2017, p. 51-58.

18. BURUIANA, D.L., ITICESCU, C., TIRON, G.L., PINTILIE, S., SIMIONESCU, C.S., BARNAURE, M., BALTA, S., Mat. Plast., 52, no.4, 2015, p. 608

19. CARBONELL-ALCAINA, C., CORBATON-BAGUENA, M.J ., ALVAREZBLANCO, S., BES-PIA, M.A., MENDOZA-ROCA, J.A., PASTOR-ALCANIZ, L., J. Food Eng., 187, 2016, p. 14-23.

20. ESQUIVEL, A., BARBEAU, B., BOUCHARD, C., Desalin. Water Treat, 8, 2009, p. 188-200.

21. WANG, Z., JIN, J., HOU, D., LIN, S., J. Memb. Sci., 516, 2016, p. 113122.

22. AHMAD, A.L., ABDULKARIM, A.A., OOI, B.S., ISMAIL, S., Chem. Eng. J., 223, 2013, p. 246-267.

23. BURUIANA, D.L., TIRON, G.L., PINTILIE, S.C., SIMIONESCU, C.S., BALTA, S., J. Mater., 45, 2015, p. 354-357.

24. SUSANTO, H., ULBRICHT, M., J. Memb. Sci., 327, 2009, p. 125-135. 25. MOON, E.J ., KIM, J.W., KIM, C.K., J. Memb. Sci., 274, 2006, p. 244251.

26. SONG, H.J ., KIM, C.K., J. Memb. Sci., 444, 2013, p. 318-326.

27. ZHANG, Y., WANG, J., GAO, F., TAO, H., CHEN, Y., ZHANG, H., Sep. Purif. Technol., 175, 2017, p. 238-247.

28. AVRAM, E., COZAN, V., Mat. Plast., 45, no.3, 2008, p. 241

29. RIKABI, A.A.K.K., NECHIFOR, A.C., MOHAMMED, T.J ., OPREA, O., MIRON, A.R., SEGARCEANU, M., VAIREANU, D.I., Rev. Chim. (Bucharest), 67, no.8, 2016, p. 1658

30. KIM, J.H., KANG, M.S., KIM, C.K., J. Memb. Sci., 265, 2005, p. 167175.

31. KIM, J.H., KIM, C.K., J. Memb. Sci., 262, 2005, p. 60-68.

32. PINTILIE, S.C., TIRON, L.G., BIRSAN, I.G., GANEA, D., BALTA, S., Mat. Plast., 54, no.2, 2017, p. 257

33. POPA, G.A., ENACHE (POPA), D.F., TANCZOS, S.K., CIOCANEA, A., Mat. Plast., 54, no.4, 2017, p. 726

34. GADEKAR, M.R., AHAMMED, M.M., Desalin. Water Treat., 57, 2016, p. 26392-26400.

35. AL-AMOUDI, A., Desalin. Water Treat., 57, 2016, p. 323-334.

36. CUCIUREANU, A., BATRINESCU, G., BADEA, N.N., RADU, D.A., NECHIFOR, G., Mat. Plast., 47, no.4, 2010, p. 416

$\overline{\text { Manuscript received: } 21.11 .2017}$ 